\title{
Vitamin D analog EB1089 triggers dramatic lysosomal changes and Beclin 1-mediated autophagic cell death
}

\author{
M Høyer-Hansen ${ }^{1}$, L Bastholm², IS Mathiasen ${ }^{1,3}$, F Elling $^{2}$ and \\ M Jäättelä*,1 \\ 1 Apoptosis Department, Institute of Cancer Biology, Danish Cancer Society, \\ Copenhagen, Denmark \\ 2 Institute of Molecular Pathology, Faculty of Health Sciences, University of \\ Copenhagen, Copenhagen, Denmark \\ ${ }^{3}$ Cancer and Immunobiology, Novo Nordisk A/S, Måløv, Denmark \\ * Corresponding author: M Jäättelä, Apoptosis Department, Institute of Cancer \\ Biology, Danish Cancer Society, Strandboulevarden 49, DK-2100 Copenhagen, \\ Denmark. Tel: + 45 35357318; Fax: + 45 35257721; \\ Email: mj@cancer.dk
}

Received 05.10.04; revised 09.3.05; accepted 23.5.05; published online 20.5.05 Edited by $\mathrm{E}$ Baehrecke

\section{Abstract}

A chemotherapeutic vitamin D analogue, EB1089, kills tumor cells via a caspase-independent pathway that results in chromatin condensation and DNA fragmentation. Employing transmission- and immunoelectronmicroscopy as well as detection of autophagosome-associated LC3- $\beta$ protein in the vacuolar structures, we show here that EB1089 also induces massive autophagy in MCF-7 cells. Interestingly, inhibition of autophagy effectively hindered apoptosis-like nuclear changes and cell death in response to EB1089. Furthermore, restoration of normal levels of beclin 1, an autophagyinducing tumor suppressor gene that is monoallelically deleted in MCF-7 cells, greatly enhanced the EB1089-induced nuclear changes and cell death. Thus, EB1089 triggers nuclear apoptosis via a pathway involving Beclin 1-dependent autophagy. Surprisingly, tumor cells depleted for Beclin 1 failed to proliferate suggesting that even though the monoallelic depletion of beclin 1 in human cancer cells suppresses EB1089-induced autophagic death, one intact beclin 1 allele is essential for tumor cell proliferation.

Cell Death and Differentiation (2005) 12, 1297-1309.

doi:10.1038/sj.cdd.4401651; published online 20 May 2005

Keywords: autophagy; Beclin 1; cancer; vitamin D; lysosomes; programmed cell death

Abbreviations: 3-MA, 3-methyladenine; BrdU, 5-bromo-2'deoxy-uridine; eGFP, enhanced green fluorescence protein; EM, electron microscopy; ER, endoplasmatic reticulum; FCS, fetal calf serum; GAPDH, glyceraldehyde-3-phosphate dehydrogenase; H2B, histone-2 beta; Hsc70, Heat-shock cognate 70 protein; LC3- $\beta$, microtubule-associated protein 1 light chain 3- $\beta$; MDC, monodansylcadaverine; MTT, 3-(4,5-dimethylthiazole-2yl)-2,5-diphenyltetrezolium bromide; PB, phosphate buffer; PBS, phosphate-buffered saline; $P C D$, programmed cell death; siRNA, short interfering RNA; TG, thapsigargin; TNF, tumor necrosis factor; VAC, volume of the acidic compartment

\section{Introduction}

Caspase-mediated apoptosis is the best-defined cell death program counteracting tumor growth. With respect to the ability of some cells to escape apoptosis, it would, however, be dangerous for the organism to depend on a single executer program for the clearance of unwanted and potentially harmful cells. Indeed, evidence for alternative death pathways where lysosomes and cathepsins function as executioners is emerging. ${ }^{1-3}$ The lysosomal membrane permeabilization followed by the release of cathepsins and other lysosomal hydrolases to the cytosol is the key event in the lysosomal death pathway. Once released to the cytosol, cathepsins, especially cysteine cathepsins $B$ and $L$ and aspartyl cathepsin $\mathrm{D}$, may trigger the mitochondrial outer membrane permeabilization followed by caspase-mediated apoptosis, ${ }^{4,5}$ or mediate caspase-independent programmed cell death (PCD). ${ }^{6,7}$ Notably, both immortalization and transformation sensitize cells to the lysosomal death pathway, ${ }^{8}$ and lysosomal membrane permeabilization can be triggered by many cancer relevant stimuli such as death receptors of tumor necrosis factor (TNF) receptor family, p53 tumor suppressor protein, DNA-damaging agents, microtubule disrupting agents and oxidative stress. ${ }^{2}$

Lysosomes are also involved in macroautophagy (hereafter referred to as autophagy), a process recently found to be deregulated in tumors. ${ }^{2,9}$ Autophagy is characterized by an increase in the number of autophagosomes, vacuoles surrounded by a double membrane, that sequester cytoplasm or organelles. Subsequently, autophagosomes fuse with lysosomes to form autolysosomes, where sequestered material is digested. During physiological conditions, constitutive autophagy plays an important role in normal protein and organelle turnover. Furthermore, autophagy can be enhanced by several cancer-related stimuli, for example, oncogenic Ras, ${ }^{10}$ starvation, ${ }^{11}$ endostatin, ${ }^{12}$ radiation, ${ }^{13}$ anti-estrogens, ${ }^{14}$ several other putative anticancer agents ${ }^{15,16}$ as well as cytokines such as TNF $^{17}$ and interferon gamma. ${ }^{11}$ An essential role for autophagy in the control of cancer progression is supported by recent data showing that beclin 1 , an autophagy gene that is monoallelically deleted in up to 40$75 \%$ of sporadic breast, ovarian and prostate cancer, acts as an effective haploinsufficient tumor suppressor in mice. ${ }^{18,19}$ The mechanism whereby autophagy provides the barrier to tumorigenesis is still speculative. Autophagy can lead to growth arrest and reduction in cell number and several death forms are associated with appearance of autophagic vesicles. $^{20}$ However, only very few data directly connect autophagy to cell death, ${ }^{14,21,22}$ and the putative signaling from autophagy to cell death is completely unknown. One possibility is that a certain amount of functional mitochondria is required for energy production and thereby for cell survival. A massive induction of autophagy could therefore lead to starvation as the cell 'cannibalizes' itself. Alternatively, lysosomal or autolysosomal membrane permeabilization 
could result in the release of cathepsins into the cytosol and cathepsin-dependent death execution. Whereas the role of cytosolic cathepsins in autophagy remains to be studied, autophagic degeneration clearly does not depend on caspase activation. ${ }^{10,23}$ Instead, autophagy can be blocked by pharmacological inhibition of class III phosphatidylinositol 3 -kinase, ${ }^{24}$ or genetic depletion of other proteins involved in the autophagosome formation, for example, Beclin 1 and $\operatorname{Atg} 7 .^{22}$ It should be noted that autophagy can serve as a protective mechanism against starvation and apoptosis by recycling macromolecules and removing damaged mitochondria and other organelles, respectively. ${ }^{16,25-27}$

EB1089, a vitamin D3 analog developed for the treatment of cancer, induces growth arrest, differentiation and cell death in malignant cells of various origins. ${ }^{28}$ In MCF-7 breast cancer cells, it triggers caspase-independent apoptosis-like PCD that is associated with an increase in intracellular free calcium $\left[\mathrm{Ca}^{2+}\right]_{\mathrm{i}}$, activation of calpain (a cytosolic calcium-regulated cysteine protease) and increased expression of cysteine cathepsins. $^{29-31}$ Despite the lack of detectable caspase activation, the dying cells present several characteristics of apoptosis, that is, rounding, shrinkage and detachment of cells as well as DNA strand breaks and fragmentation.

Our earlier observations showing that EB1089-treated MCF-7 cells display a dramatic increase in intracellular vacuoles and cysteine cathepsin expression prompted us to study the possible role of lysosomes and autophagy in EB1089-induced PCD. To this end, we compared EB1089induced lysosomal changes to those induced by TNF and thapsigargin (TG; an irreversible inhibitor of Serca, an endoplasmatic reticulum calcium ATPase). TNF was chosen as a 'control' treatment because it can in addition to the wellcharacterized caspase-dependent apoptosis pathway induce lysosomal membrane permeabilization ${ }^{6}$ and/or autophagy, ${ }^{17}$ and TG, because it akin to EB1089 triggers both early and delayed increase in $\left[\mathrm{Ca}^{2+}\right]_{\mathrm{i}}{ }^{32}$ We find that cell death induced by EB1089 is associated with autophagy, and that monoallelic deletion of beclin 1 confers partial resistance to EB1089. We also show that tumor cell growth is severely compromised upon knockdown of Beclin 1, suggesting a dual role for Beclin 1 in cancer progression.

\section{Results}

\section{EB1089, TNF and TG trigger early changes in volume and integrity of the acidic compartment}

To assess the effect of EB1089, TNF and TG on the lysosomal compartment, we investigated the volume of the acidic compartment (VAC) by staining MCF-7 breast cancer cells with lysotracker-red, a basic cell-permeable probe that accumulates in acidic vesicles. Confocal microscopy revealed a dramatic increase in the size and number of acidic vesicles in response to EB1089 (100 nM for 5 days) and TNF $(10 \mathrm{ng} / \mathrm{ml}$ for $24 \mathrm{~h}$ ), whereas TG-treated ( $10 \mathrm{nM}$ for $48 \mathrm{~h}$ ) cells had almost completely lost their ability to accumulate lysotrackerred (Figure 1a). In EB1089-treated cells, the increase in VAC was associated with an increase in total cysteine cathepsin activity reflecting enhanced lysosomal activity (Figure 1a and b). Similarily, TG-induced decrease in lysotracker-red staining was associated with decreased total cysteine cathepsin activity, whereas cells treated with TNF for $24 \mathrm{~h}$ had slightly decreased lysosomal protease activity in spite of increased VAC (Figure 1a and b). This could reflect the ability of TNF and possibly also TG to induce lysosomal membrane permeabilization. Indeed, TNF-treated MCF-7 cells displayed lysosomal membrane permeabilization that started $12-15 \mathrm{~h}$ after the addition of TNF, and the TG-induced loss of VAC was associated with a time-dependent destabilization of lysosomes resulting in a complete release of cysteine cathepsin activity from the lysosomes into the cytosol (Figure 1c and data not shown). Contrary to TNF and TG, EB1089 did not change the ratio between cytosolic and total cysteine cathepsin activities (Figure 1c). It should, however, be noted that the absolute cytosolic cysteine cathepsin activity increased also in EB1089-treated cells due to an over 2.5-fold increase in the total activity (Figure 1b). EB1089-induced increase in VAC (not shown) and lysosomal protease activity were time-dependent starting before any apparent changes in cell morphology (not shown) or DNA fragmentation were detectable, that is, by one day of the treatment (Figure $1 \mathrm{~b}$ and d). Lysosomal changes (VAC and lysosomal leakage) preceded changes in cell morphology and DNA fragmentation also in TNF-and TG-treated cells (Figure 1b-d and data not shown).

\section{EB1089 and TNF increase the uptake of monodansylcadaverine in MCF-7 cells}

Next, we examined whether the changes in VAC observed in EB1089-, TNF- and TG-treated cells were associated with altered autophagy. For this purpose we stained the drugtreated cells with monodansylcadaverine (MDC), an autofluorescent base that has been reported to accumulate in autophagic vacuoles, ${ }^{33}$ and analyzed them by fluorescence microscopy. MCF-7 cells displayed only very few weakly staining granules, whereas approximately $40 \%$ of EB1089and $30 \%$ of TNF-treated cells accumulated MDC into granular structures of high fluorescence intensity (Figure $2 a$ and $b$ ). TG-treated cells showed an increase in diffuse cytosolic staining, but a complete lack of the granular staining (Figure $2 \mathrm{a}$ and $\mathrm{b}$ ). The TNF-induced granular staining and the TGinduced increase in the cytosolic MDC staining observed in microscopic analysis were quantified by spectrofluorometer analysis of live cells that revealed approximately 1.8- and 2.1-fold increase in fluorescence intensity, respectively (Figure 2c). In order to test whether MDC-positive vacuoles were of autophagic origin, we added $10 \mathrm{mM}$ 3-methyladenine (3-MA), an inhibitor of class III phosphatidylinositol 3-kinase and autophagosome formation, ${ }^{34}$ to the cells 2 days before the analysis. Surprisingly, 3-MA treatment alone increased both the number of MDC-positive cells and especially the intensity of the staining (Figure $2 b$ and $c$ ). It also failed to significantly inhibit the EB1089- and TNF-induced increase in the number of MDC-positive cells questioning the specificity of the probe (Figure 2b). Indeed, costaining of EB1089- and TNF-treated MCF-7 cells with MDC and lysotracker-red revealed nearly complete colocalization of the probes, suggesting that they accumulate in same organelles, 

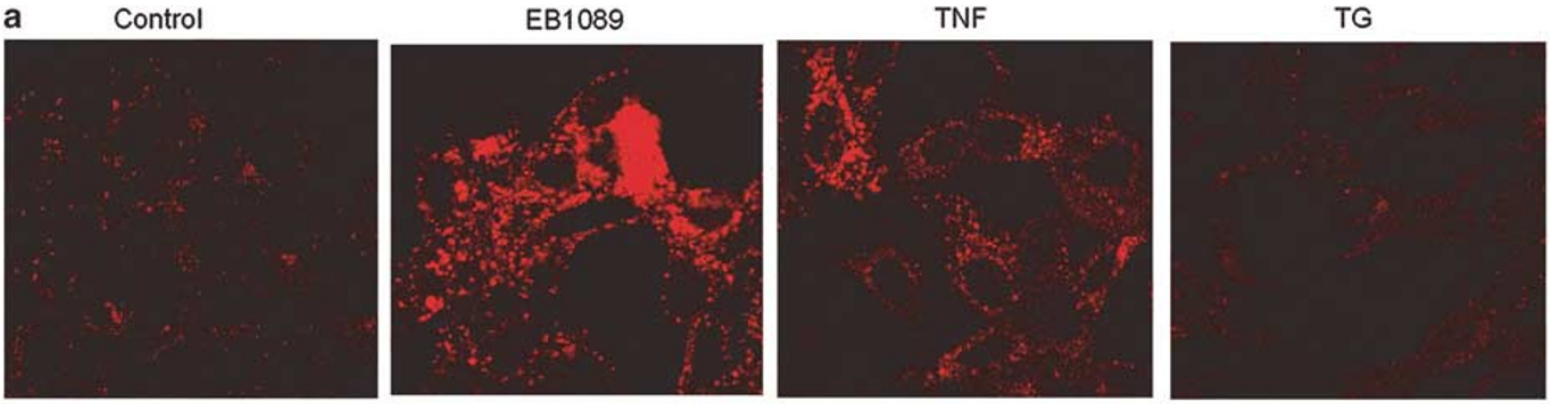

b
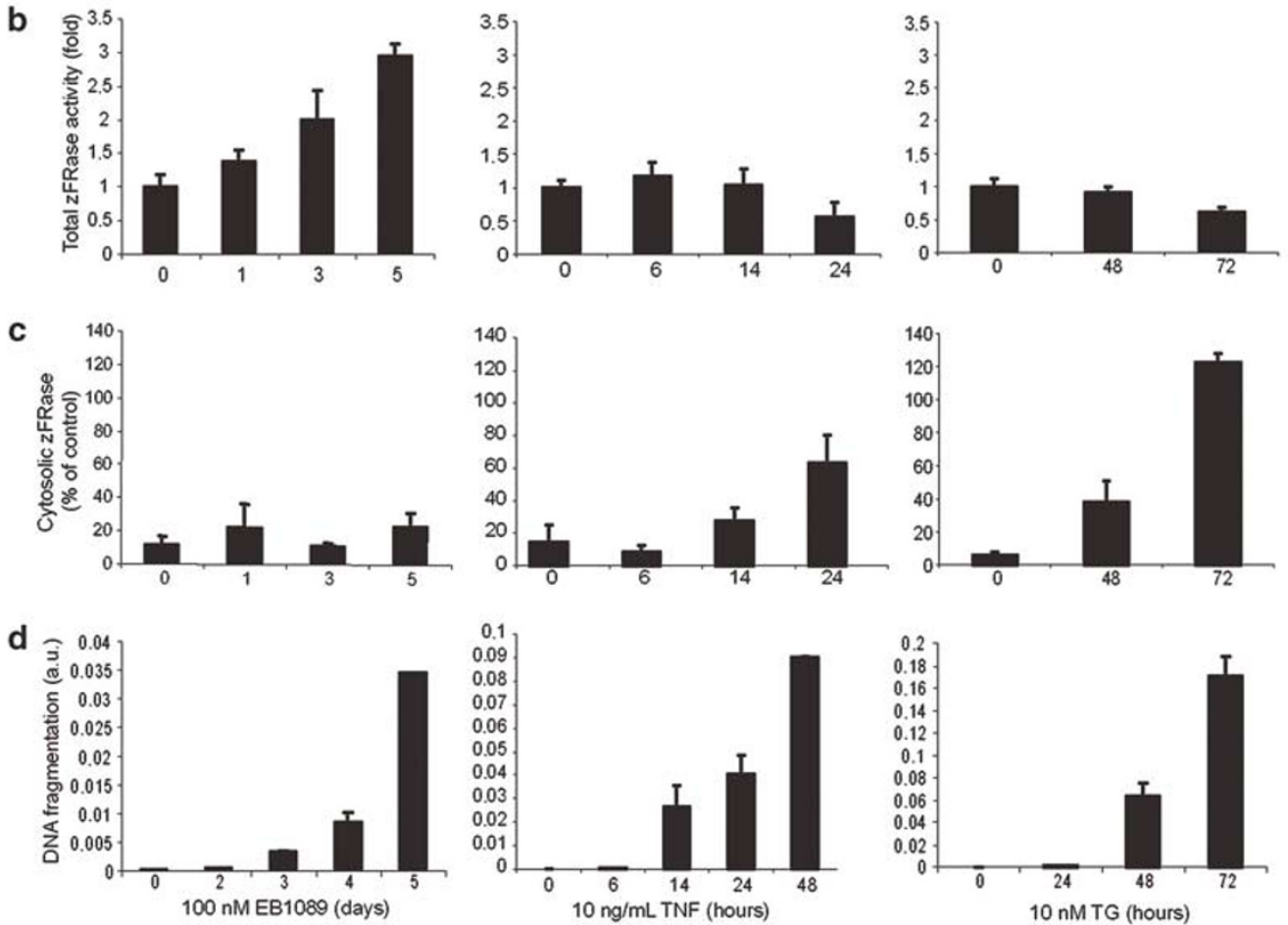

Figure 1 EB1089-, TNF- and TG-induced changes in lysosomes precede cell death. (a) Accumulation of lysotracker-red was analyzed in MCF-7 cells left untreated (control) or treated with $100 \mathrm{nM} \mathrm{EB} 1089$ for 5 days, $10 \mathrm{ng} / \mathrm{ml} \mathrm{TNF}$ for $24 \mathrm{~h}$ or $10 \mathrm{nM}$ TG for $48 \mathrm{~h}$ by confocal microscope. Pictures were taken and modified using identical settings and are representative of a minimum of two independent experiments. (b, c) MCF-7 cells treated as indicated were analyzed for total (b) and cytosolic (c) cysteine cathepsin activities (zFRase). All protease activities are normalized to the lactate dehydrogenase activity in the same sample. The total activity is expressed relative to that in vehicle-treated cells, and the cytosolic activity as a percentage of the total activity. The values represent means of triplicate determinations \pm S.D. (d) DNA fragmentation in MCF-7 cells treated as indicated was measured by the ELISA method and is expressed as arbitrary units corresponding to the absorbance divided by the number of cells in an identically treated parallel sample. The values represent means of duplicate determination \pm S.D. All experiments were repeated at least twice with essentially same results

presumably lysosomes (Figure 2d). Accordingly, MDC failed to differentiate between lysosomes and autophagic vesicles also in MCF-7 cells treated with known inducers of autophagy, that is, tamoxifen and rapamycin (Figure 2d)..$^{14,35}$ It should also be noted that all the MDC stainings presented above were performed in live cells. Fixation of the cells with $3.7 \%$ formaldehyde almost completely abrogated the granular staining even in cells known to accumulate autophagosomes (data not shown).

\section{EB1089 induces autophagy in MCF-7 cells}

To detect the formation of autophagic vesicles in a more reliable manner, we expressed a fusion protein consisting of DsRed1 and microtubule-associated protein 1 light chain 3- $\beta$
(LC3- $\beta$ ), a human ortholog of a yeast autophagy protein Atg8, ${ }^{36}$ together with histone-2 beta-enhanced green fluorescence protein fusion protein (H2B-eGFP) in MCF-7 cells. To verify that DsRed1-LC3- $\beta$ translocated to autophagic vesicles as reported earlier, ${ }^{36}$ we treated the transfected cells with tamoxifen or rapamycin. Whereas control cells displayed a very weak diffuse staining with a few red granules, large proposition of the cells treated with either drug displayed strong red granular staining as analyzed by confocal microscopy (Figure 3a and b). To further validate the assay, we cotransfected DsRed1-LC3- $\beta$ with GFP-tagged rat LC3- $\beta$ that has been shown to localize to autophagic membranes. ${ }^{37}$ The proteins showed nearly complete colocalization both in untreated (weak diffuse staining) and autophagic (punctuate) cells (data not shown). Therefore, we concluded that 

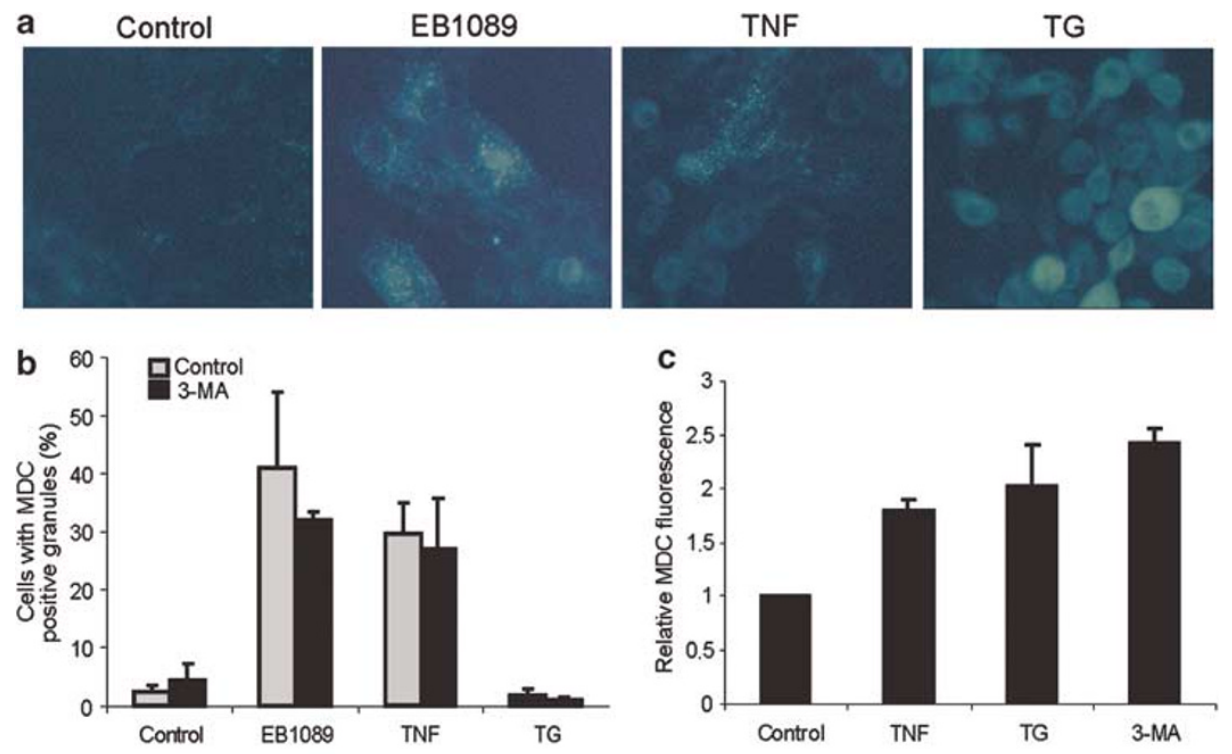

d

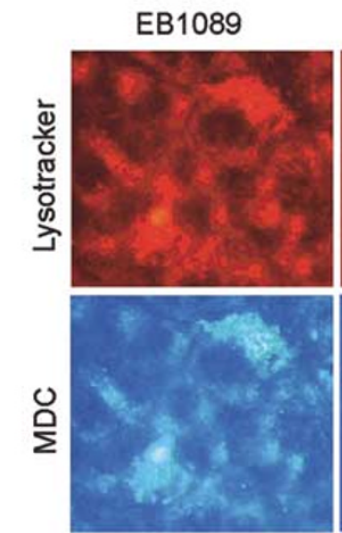

TNF

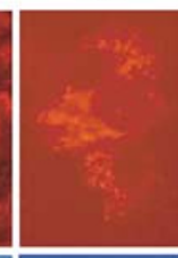

\section{Tamoxifen}

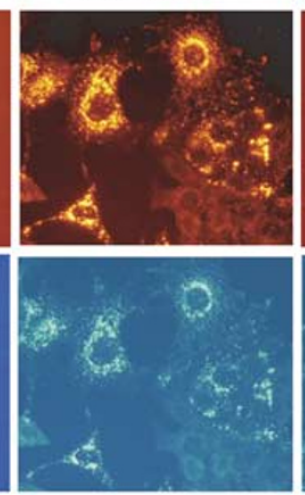

Rapamycin

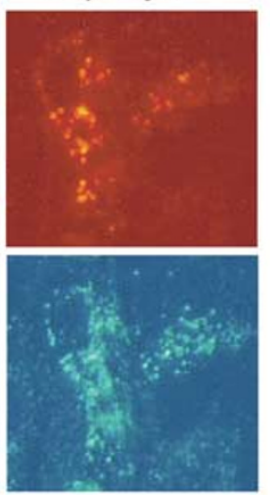

Figure 2 EB1089 and TNF increase the uptake of MDC in MCF-7 cells. (a and b) MCF-7 cells were left untreated (control) or treated with $100 \mathrm{nM} \mathrm{EB1089}$ for 5 days, $10 \mathrm{ng} / \mathrm{ml}$ TNF for $24 \mathrm{~h}$ or $10 \mathrm{nM}$ TG for $48 \mathrm{~h}$ before MDC staining. (a) The pictures applying an inverted fluorescence microscope (Olympus IX-70) connected to a digital camera (Olympus, c-5050) were taken manually using identical exposure conditions and postexposure modifications. (b) The number of cells with a granular positive MDC staining was counted (a minimum of 100 cells/sample) and the values represent means of three independent experiments \pm S.D. When indicated, $10 \mathrm{mM} 3-\mathrm{MA}$ was added at day 3 of EB1089 treatment or simultaneously with TNF and TG. (c) The cells were left untreated or treated with $10 \mathrm{ng} / \mathrm{ml}$ TNF, $10 \mathrm{nM}$ TG or $10 \mathrm{mM} 3-\mathrm{MA}$ for $36 \mathrm{~h}$ before MDC staining. The MDC-fluorescence (excitation $355 \mathrm{~nm}$; emission $460 \mathrm{~nm}$ ) was measured by a fluorometer and corrected to cell density measured by the MTT reduction assay performed in parallel. The values are arbitrary units showing MDC-fluorescence/cell relative to untreated cells and represent means of three independent triplicate experiments \pm S.D. (d) Cells were treated with $100 \mathrm{nM}$ EB1089 for 3 days, $10 \mathrm{ng} / \mathrm{ml} \mathrm{TNF}$ for $24 \mathrm{~h}, 2.5 \mu \mathrm{M}$ tamoxifen for 5 days or $10 \mu \mathrm{M}$ rapamycin for 3 days before costaining with lysotracker-red and MDC and imaging using an inverted fluorescence microscope. The experiment was repeated twice with similar results

DsRed1-LC3- $\beta$ translocated as expected upon autophagy induction and we applied this system to test whether the accumulation of MCD-positive acidic vesicles in response to EB1089 and TNF was due to autophagy. Approximately $20 \%$ of MCF-7 cells treated with EB1089 showed a dramatic increase in red vesicles (Figure 3b). The increase in LC3- $\beta$ positive vacuoles became evident after 1-2 days and increased until 4 days (data not shown). In contrast to EB1089, TNF failed to trigger the translocation of LC3- $\beta$ (Figure $3 a$ and $b$ ). We were not able to test the ability of 3-MA to inhibit the translocation of LC3- $\beta$, because 3-MA itself increased the number of cells with DsRed1-LC3- $\beta$ localized to granular structures (data not shown). Instead, we compared the DsRed1-LC3- $\beta$ localization with MDC staining in cells treated with EB1089, TNF or tamoxifen. Even though there was an overlap in the staining patterns, DsRed1-LC3- $\beta$ also stained several MDC-negative vesicles in EB1089- and tamoxifen-treated cells, and vice versa, MDC stained numerous DsRed1-LC3- $\beta$-negative vesicles in cells treated with EB1089, TNF or tamoxifen (Figure 3c). These data suggest that LC3- $\beta$, indeed, localizes to both neutral and acidic vesicles presumably representing autophagosomes and autolysosomes, respectively (Figure 3 ).

To further elucidate the origin of the vacuoles and other morphological changes induced by EB1089, TNF and TG, we examined the morphology of the dying MCF-7 cells by transmission electron microscopy (EM) (Figure 4). As we have shown previously, 5-day treatment with EB1089 induced an apoptosis-like nuclear morphology characterized by a partially condensed chromatin marginalized along the nuclear 
a

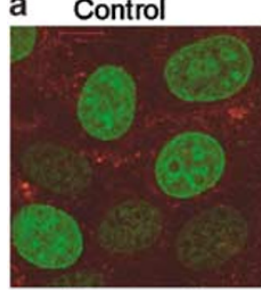

Rapamvcin

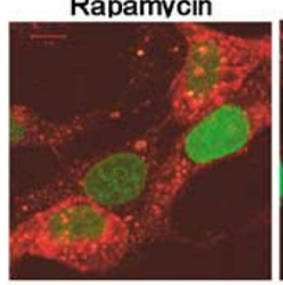

b

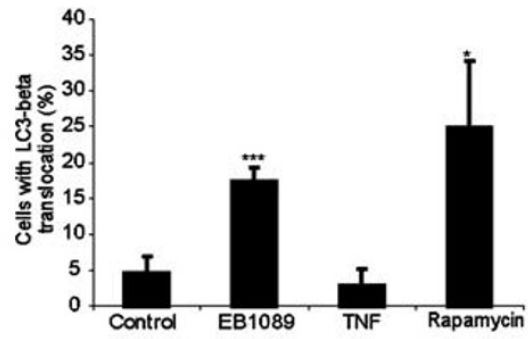

C
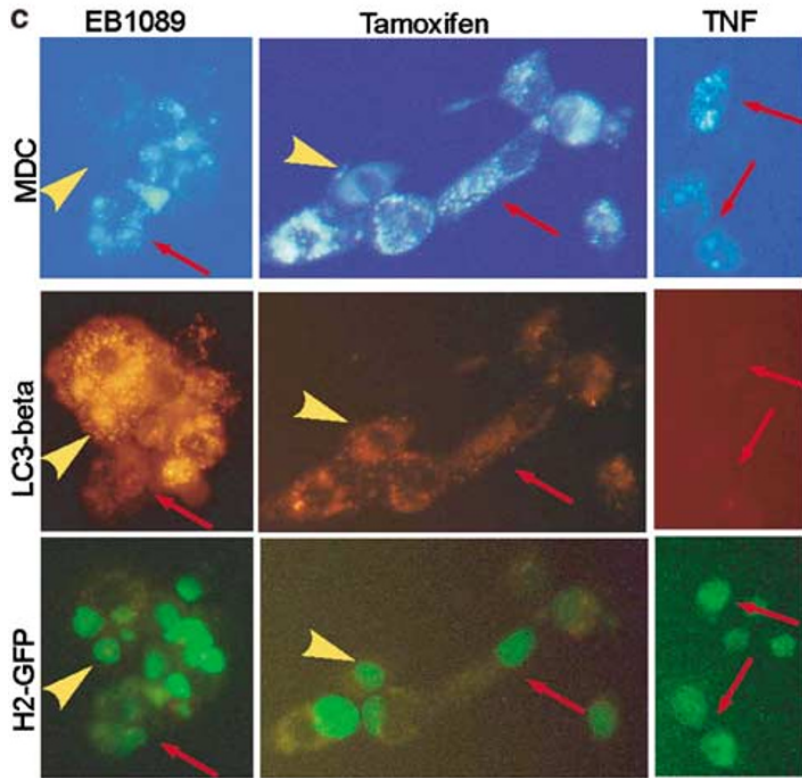

Figure 3 EB1089 treatment triggers the translocation of LC3- $\beta$ into granula structures in MCF-7 cells. MCF-7 cells were transfected with pDsRed1-LC3- $\beta$ and $\mathrm{pH} 2 \mathrm{~B}-\mathrm{eGFP}$ at the ratio $4: 1$ by electroporation. Transfected cells were left untreated for 6 days (control) or treated 5 days after the transfection with $10 \mathrm{ng} / \mathrm{ml} \mathrm{TNF}$ for $24 \mathrm{~h}$ or 1 day after the transfection with $100 \mathrm{nM}$ EB1089, $10 \mu \mathrm{M}$ rapamycin or $2.5 \mu \mathrm{M}$ tamoxifen for 5 days. (a) Images of the transfected cells treated as indicated were taken on a confocal laser scanning microscope using identical settings and image modifications. (b) The percentage of cells with DsRed1-LC3- $\beta$ localized to granular structures was estimated by counting a minimum of 100 H2B-eGFP-postive cells. The values represent means of five independent experiments + S.D. (c) After the indicated treatments, cells were incubated with $50 \mu \overline{\mathrm{M}} \mathrm{MDC}$ for $30 \mathrm{~min}$ followed by $40 \mathrm{mM} \mathrm{NH}_{4} \mathrm{Cl}$ for $10 \mathrm{~min}$. Pictures were taken applying an inverted fluorescence microscope. The experiment was repeated once with similar results. ${ }^{*} P$-value $<0.05$, ${ }^{* \star *} P$-value $<0.001$; as compared with untreated control cells (two sample $t$-test) envelope (Figure 4f). A more compact chromatin condensation was observed in cells treated with TNF or TG (Figure $4 \mathrm{~g}$ and $h$ ). All three stimuli increased the number of electron light vesicles. Almost all TG-induced vesicles were surrounded by ribosomes and were therefore likely to originate from rough endoplasmatic reticulum (ER) (Figure 4h). Also, EB1089treated cells had some ribosome-containing vesicles (data not shown) in agreement with earlier data showing that both TG and EB1089 induce ER stress. ${ }^{31,38}$ Additionally, cells treated with EB1089 and TNF had an extraordinary induction of ribosome-free vesicles consistent with the massive VAC increase triggered by both drugs (Figure $4 c-g$ ). Contrary to either normal or slightly condensed mitochondria in cells treated with TNF or TG (Figure $4 \mathrm{~g}$ and $\mathrm{h}$ ), dramatic mitochondrial changes characterized by breakage and removal of the cristae were apparent in cells treated with EB1089 (Figure 4c-f). Damaged mitochondria were found already 2 days after the treatment (Figure 4c), and they were also frequent in cells without chromatin condensation (Figure $4 c-e)$. The atypical mitochondria were commonly surrounded by a double membrane typical of autophagosomes (Figure $4 d-f)$. Furthermore, some EM pictures revealed an ongoing fusion between lysosome-like and autophagosome-like structures (Figure 4e). Changes characteristic of autophagy were also induced by the active form of vitamin D3, 1,25-dihydroxyvitamin $D_{3}$ (data not shown). Furthermore, immuno-EM of the atypical mitochondria-like structures in EB1089-treated cells demonstrated that they contained cathepsin D (lysosomal marker), Heat-shock protein 60 (Hsp60) and cytochrome $c$ (mitochondrial markers) indicative of autolysosomes (Figure $5 \mathrm{a}$ and $\mathrm{b}$, data not shown). Moreover, they stained positive for Serca-2 (ER marker) possibly as a result of autophagy of the dilated ER (Figure 5c). Alternatively, the autophagy-membrane may have originated from the ribosomefree regions of the rough ER as suggested previously. ${ }^{39}$

\section{EB1089-induced cell death is inhibited by 3-MA}

To investigate the role of autophagic activity in EB1089induced death signaling, we treated MCF-7 cells with $10 \mathrm{mM}$ 3-MA for the last 2 days of the 5-day treatment with EB1089. 3-MA not only inhibited the EB1089-induced appearance of damaged mitochondria and autophagic vesicles but also the condensation of chromatin as analyzed by EM (Figures 4f, $6 \mathrm{a}$ and b). Furthermore, 3-MA inhibited EB1089-induced rounding and detachment of the cells as analyzed by phase contrast microscopy (data not shown), DNA fragmentation (Figure 6c) as well as permeabilization of the plasma membrane (Figure 7e). In accordance with the lack of autophagic markers in TNF- and TG-treated cells, 3-MA failed to inhibit morphological changes, rupture of the outer membrane and DNA fragmentation induced by these stimuli (Figure 6C and data not shown).

An autophagy-associated tumor suppressor gene beclin 1 is monoallelically deleted in MCF-7 cells. ${ }^{40,41}$ To test whether this deletion confers resistance to EB1089-mediated autophagic cell death demonstrated above, we increased the expression level of Beclin 1 by ectopic expression. We established several Beclin 1-expressing single cell clones and selected two clones with approximately a doubling in the 


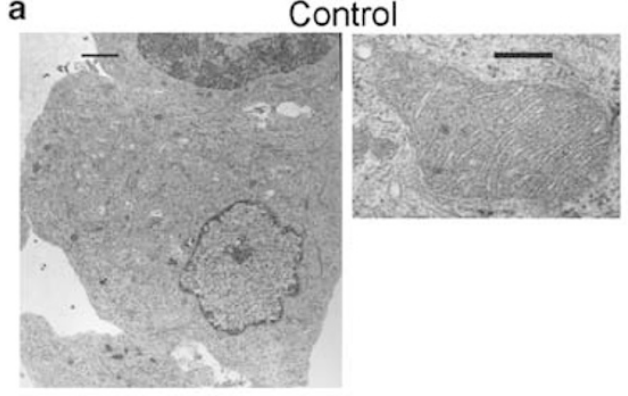

e

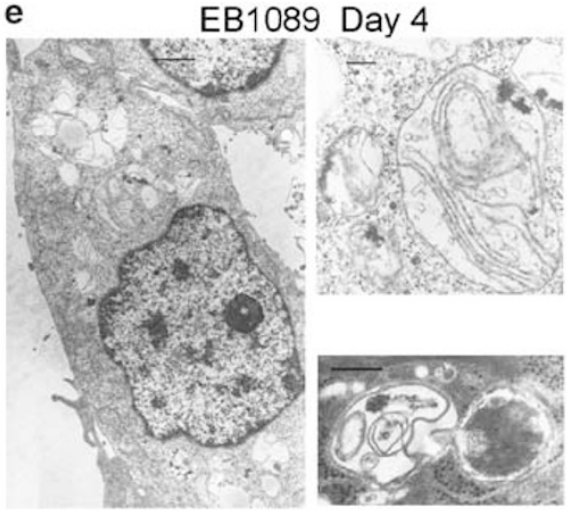

b EB1089 Day 1

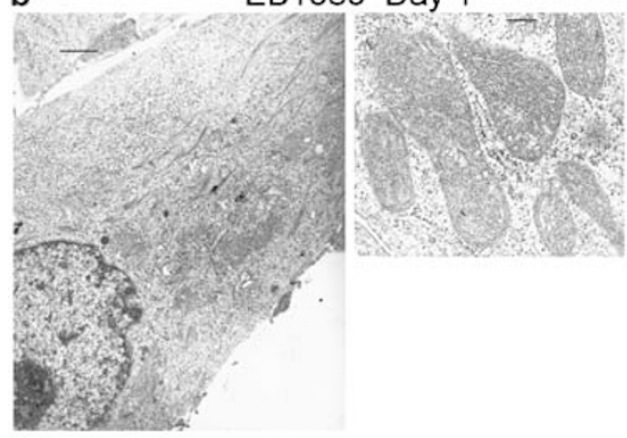

C

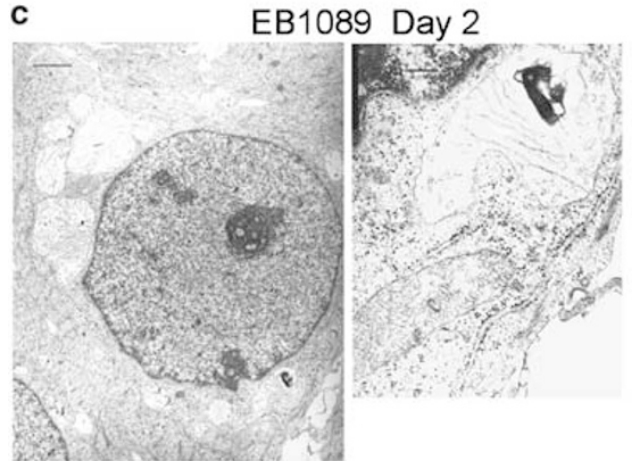

d

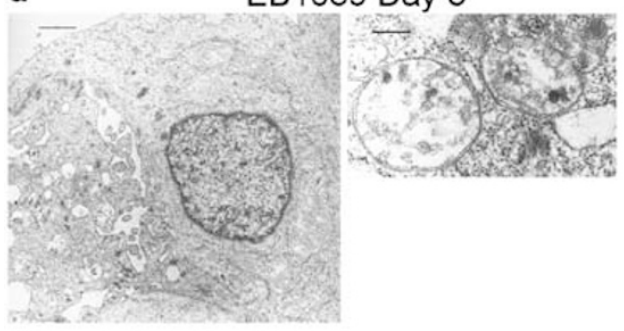

f

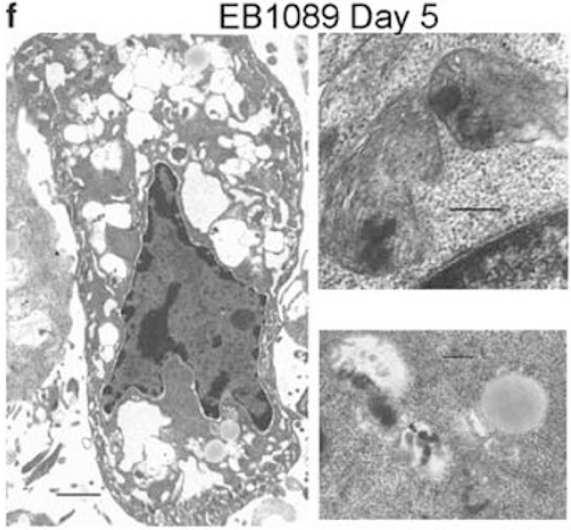

g

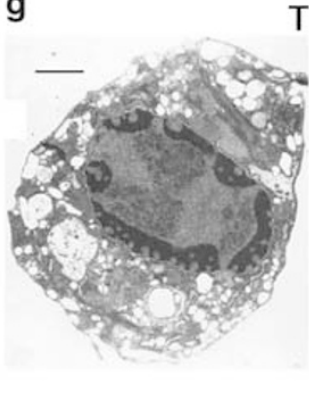

TNF

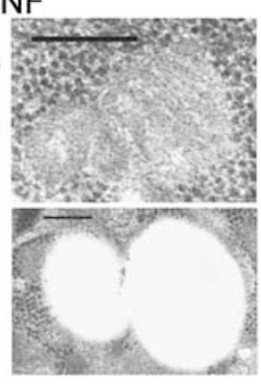

h

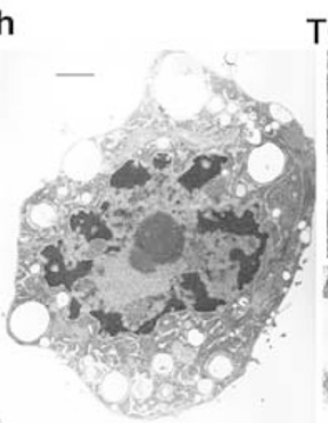

TG

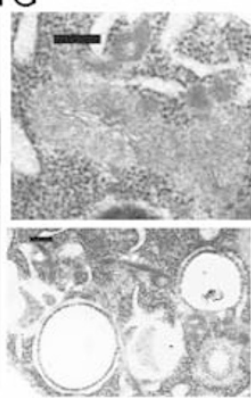

Figure 4 EB1089 induces autophagy in MCF-7 cells. Transmission EM images of MCF-7 cells left untreated (a) or treated with $100 \mathrm{nM}$ EB1089 for the indicated times $(\mathbf{b}-\mathbf{f})$, or $10 \mathrm{ng} / \mathrm{ml}$ TNF $(\mathbf{g})$ or $10 \mathrm{nM} \mathrm{TG}(\mathbf{h})$ for 2 days are shown. The larger images on the left were taken with a $\times 5000$ objective ( $1 \mu \mathrm{M}$ scale bars) and the close-up images of intracellular organelles on the right with $\mathrm{a} \times 20000$ objective $(0.2 \mu \mathrm{M}$ scale bars $)$

expression for further analysis (Figure 7a). Ectopic expression of Beclin 1 increased the EB1089-induced degradation of long-lived proteins consistent with increased autophagic activity (Figure 7b). Furthermore, Beclin 1 expression sensitized MCF-7 cells to EB1089-induced growth inhibition and cell death as analyzed by 3-(4,5-dimethylthiazole-2-yl)- 
2,5-diphenyltetrezolium bromide (MTT) reduction assay, phase contrast microscopy, exclusion of vital dye and DNA
Anti-CathD

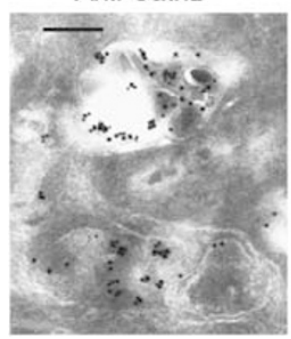

Anti-Hsp60

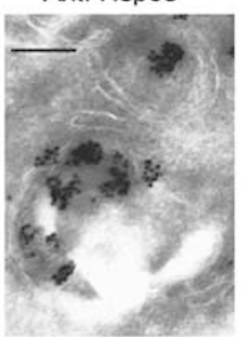

Anti-Serca

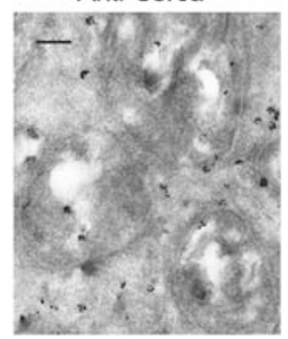

Figure 5 EB1089-induced autophagosomes contain mitochondrion-, Iysosome- and ER-derived proteins. Representative cryoimmuno-EM images of MCF-7 cells treated with $100 \mathrm{nM}$ EB1089 for 5 days and labeled with polyclonal rabbit antibodies against cathepsin $\mathrm{D}$ (CathD; lysosome) or monoclonal murine antibodies against Heat-shock protein 60 (Hsp60; mitochondrion) and Serca (ER) and appropriate gold-labeled secondary antibodies. Cathepsin D, Hsp60 and Serca were detected inside the double membrane-surrounded structures some of which still contained recognizable mitochondrial cristae. Monoclonal murine antibodies against cathepsin $D$ resulted in the labeling of the same structures. The omission of primary or secondary antibodies or replacement of primary antibodies with mouse IgG1 showed practically no staining. Scale bars are $0.2 \mu \mathrm{m}$ fragmentation assay (Figure 7c-f). Remarkably, Beclin 1expressing cells started to die already $50-63 \mathrm{~h}$ after the addition of EB1089, that is, approximately 1 day before any death was evident in parental MCF-7 cells or vectortransfected control cells. Akin to parental MCF-7 cells, cotreatment with 3-MA conferred almost complete protection against EB1089-induced cell death in Beclin 1-expressing cells, suggesting that Beclin 1-mediated sensitization was due to increased autophagy. Accordingly, Beclin 1 expression did not sensitize MCF-7 cells to nonautophagic cell death induced by TNF or TG (Figure 7c).

\section{Beclin 1 is required for the proliferation of cancer cells}

In order to test whether EB1089-induced autophagic PCD was dependent on Beclin 1, we depleted MCF-7 cells for Beclin 1 by two independent and nonoverlapping small interfering RNAs (siRNA) (Figure 8a and data not shown). We were, however, unable to assess this question, because the Beclin 1-depleted MCF-7 cells ceased to grow and displayed stressed morphology with numerous long filopodia (Figure 8b). This phenotype was evident already 2 days after
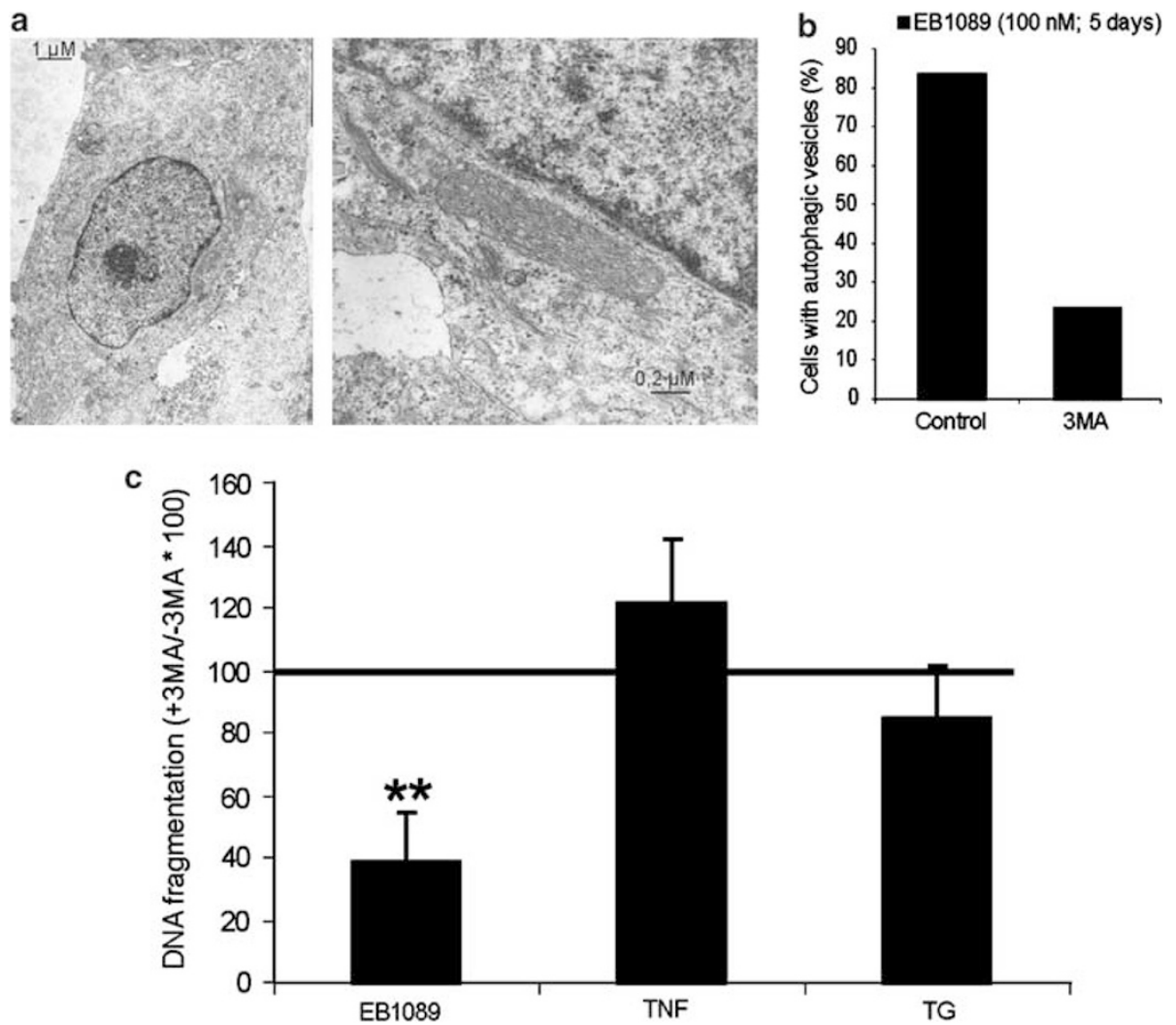

Figure 6 Inhibition of autophagy rescues MCF-7 cells from EB1089-induced PCD. (a) Transmission EM images of MCF-7 cells treated with $10 \mathrm{mM} 3-\mathrm{MA}$ for the last 2 days of a 5-day treatment with $100 \mathrm{nM}$ EB1089. Compare with Figure 4F and note the ability of 3-MA to completely inhibit the EB1089-induced mitochondrial damage, autophagosome formation and chromatin condensation. (b) The data were quantified by counting the number of cross-sectioned cells with autophagic vesicles $(n=30)$. (c) MCF-7 cells were treated with $100 \mathrm{nM}$ EB1089 for 5 days or $10 \mathrm{ng} / \mathrm{ml} \mathrm{TNF}$ or $10 \mathrm{nM}$ TG for 2 days. When indicated, $10 \mathrm{mM} 3-\mathrm{MA}$ was added for the last 2 days of the experiment. The cytosolic histone-bound DNA fragments were measured using an ELISA kit. The amount of cytosolic DNA fragments was correlated to the cell number in identically treated parallel samples. The values are expressed as percentages of DNA fragmentation in drug plus 3-MA-treated samples as compared to the samples treated with the drug alone, and they represent averages of three (TG and TNF) or four (EB1089) independent duplicate determinations \pm S.D. ${ }^{\star \star} P$-value $<0.01$; as compared with cells treated with the drug alone (one sample $t$-test) 

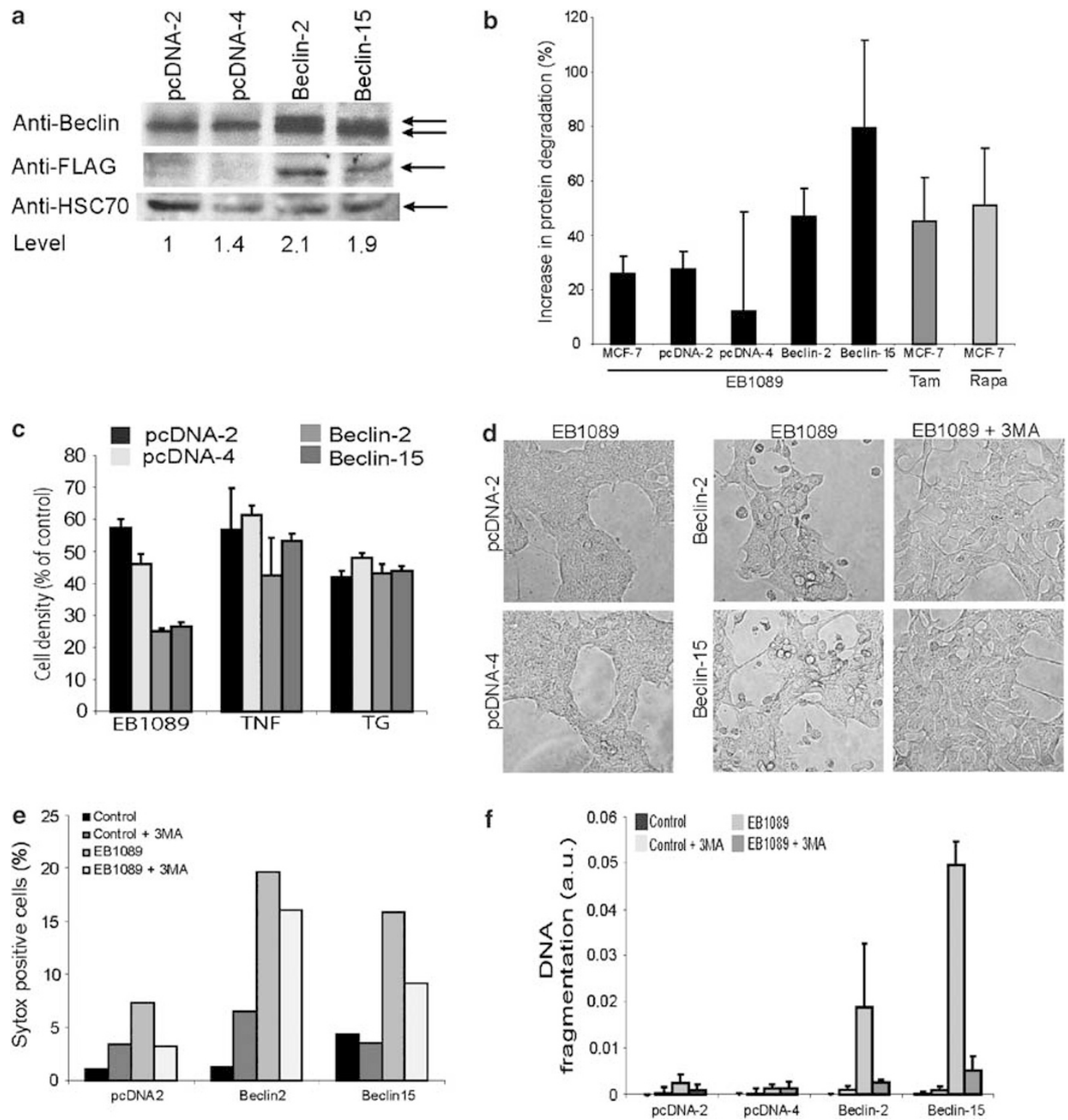

Figure 7 Ectopic expression of Beclin 1 sensitizes MCF-7 cells to EB1089-induced PCD. MCF-7 cells were transfected with either an empty pcDNA3 vector or pCRFlag-Beclin 1 and two vector transfected (pcDNA-2 and -4) and two Flag-Beclin 1 expressing (Beclin-2 and -15) single cell clones were further analyzed. (a) Proteins from indicated single cell clones were analyzed for Beclin 1, Flag-Beclin 1 and Hsc70 by immunoblotting. The densitometry program IMAGEJ was applied to quantify the Beclin 1 level and the values shown are the averages from three experiments. (b) The increase in the degradation of long-lived proteins in parental (MCF-7), vector(pcDNA-2 and pcDNA-4), and Beclin 1-transfected (Beclin-2 and Beclin-15) MCF-7 cells treated with EB1089 (100 nM for 2 days), tamoxifen (Tam; $2,5 \mu \mathrm{M}$ for 2 days) or rapamycin (Rapa; $5 \mu \mathrm{M}$ for 2 days) was analyzed. The results are shown as the percentage increase in the radioactivity in the culture media/total radioactivity upon indicated treatments. The values represent averages of two independent duplicate experiments \pm S.D. (c) The cell density of cells left untreated or treated with $100 \mathrm{nM}$ EB1089 for $72 \mathrm{~h}, 5 \mathrm{ng} / \mathrm{ml}$ TNF for $24 \mathrm{~h}$ or $5 \mathrm{nM} \mathrm{TG}$ for $48 \mathrm{~h}$ was measured by the MTT reduction assay and is expressed as percentage of vehicle-treated cells. The values represent averages of triplicate determinations \pm S.D. Similar results were obtained in three independent experiments. (c, $\mathbf{d})$ The indicated single cell clones were treated with the vehicle (control) or $100 \mathrm{nM} \mathrm{EB} 1089$ for $63 \mathrm{~h}$ with or without $10 \mathrm{mM} 3-\mathrm{MA}$ during the last $48 \mathrm{~h}$ of the incubation. The phase contrast images were taken on an inverted light microscope (d), lysis of cell membrane was quantified by flow cytometry analysis of sytox-positive cells (e) and the cytosolic histone-bound DNA fragments were measured using an ELISA kit (f). The amount of cytosolic DNA fragments was correlated to the cell number in identically treated parallel samples. The values are expressed as arbitrary units, and they represent averages of three independent duplicate experiments \pm S.D.

the siRNA transfection and increased with time (data not shown). To test whether Beclin 1 was also required for the growth of other cancer cells, we depleted HeLa cervix carcinoma cells for Beclin 1 (Figure 8a). Whereas control siRNA-transfected cells grew normally, the morphology of HeLa cells depleted for Beclin 1 changed dramatically already 2 days after transfection. The obtained morphology was reminiscent of senescence characterized by large flattened cells, some with long outwards protrusions (Figure $8 \mathrm{~b}$ ). Moreover, depletion of Beclin 1 in MCF-7 and HeLa cells resulted in a dramatic reduction in cell number, as analyzed by phase contrast microscopy and manual cell counting (Figure $8 \mathrm{~b}$ and $\mathrm{c}$ ). The reduced cell growth in Beclin 1-depleted cells was verified by a significant decrease in DNA synthesis 
a
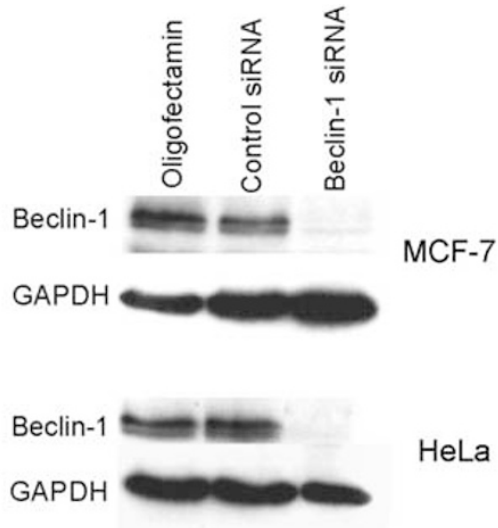

C

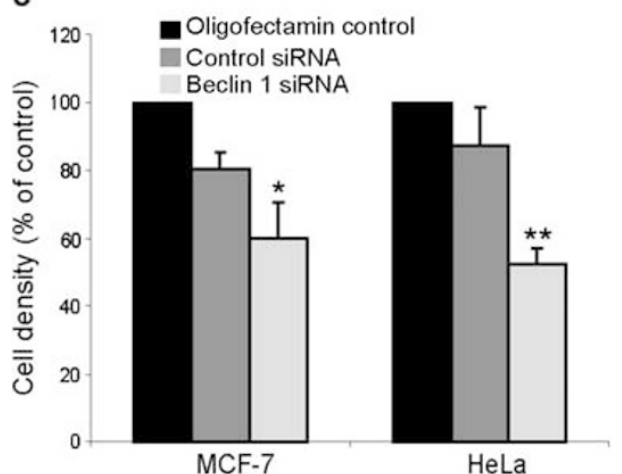

b

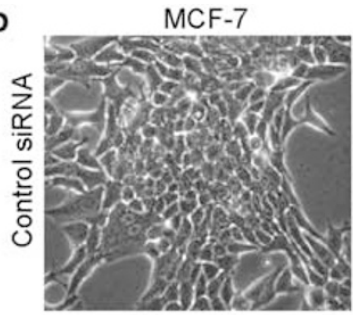

MCF-7
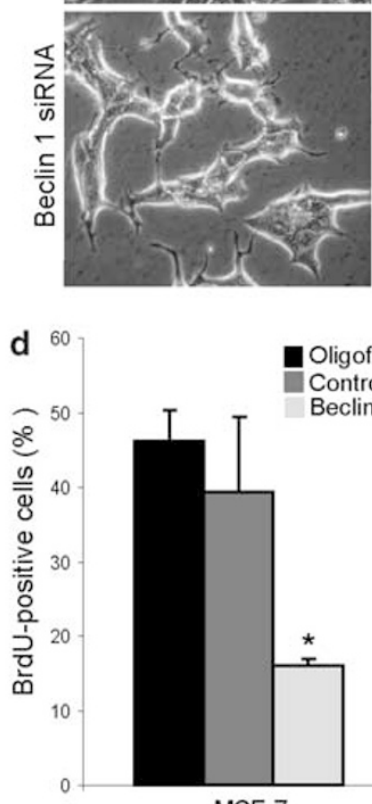

MCF-7
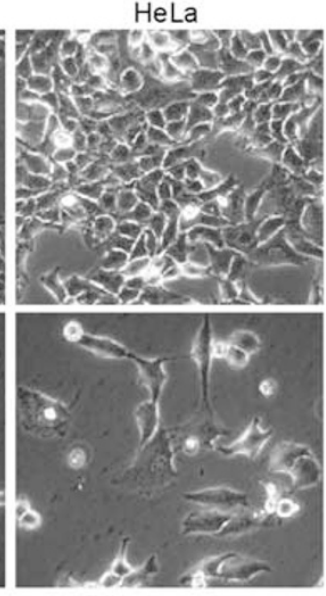

ctamin trol siRNA lin siRNA

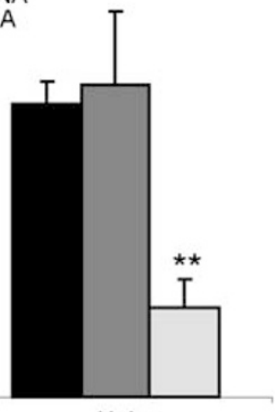

Figure 8 Depletion of Beclin 1 induces growth arrest in MCF-7 and HeLa cells. MCF-7 and HeLa cells were transfected with oligofectamin without RNA, with control siRNA or with siRNA against Beclin 1 and analyzed $72 \mathrm{~h}$ later for (a) the expression of Beclin 1 and glyceraldehyde-3-phosphate dehydrogenase (GAPDH) by immunoblotting, (b) morphology by phase contrast microscopy, (c) cell density by cell counting and (d) DNA synthesis by BrdU-incorporation assay. (c) The cell density is expressed as a percentage of oligofectamin-treated control cells. The values represent averages of three (HeLa) or four (MCF-7) independent triplicate experiments. (d) The values show the percentage of BrdU-positive cells and represent averages of three independent triplicate experiments \pm S.D. ${ }^{\star} P$-value $<0.05$, ${ }^{*} P$-value $<0.01$;as compared with cells treated with control siRNA (two-sample $t$-test). Similar results were obtained when employing a nonoverlapping Beclin 1 siRNA (see Materials and Methods) to deplete Beclin-1

(Figure 8d). Accordingly, analysis of the cell cycle distribution revealed a significant reduction in the percentage of $S$ phase cells in Beclin 1-depleted MCF-7 and HeLa cells (data not shown).

\section{Discussion}

Since the identification of Beclin 1 as a tumor suppressor protein that mediates autophagy and thereby slows down the growth of tumor cells, ${ }^{40}$ there have been several reports providing evidence for autophagy-mediated negative control of tumorigenesis. ${ }^{2,9}$ PTEN, Bin1 and death-associated protein kinase are among the autophagy-promoting proteins that akin to Beclin 1 display tumor suppressive properties. Furthermore, tumor cells originating from cancer types that rarely carry activating mutations in the ras proto-oncogene (e.g. glioblastomas and gastric carcinomas) show increased autophagy and decreased survival upon ectopic expression of activated Ras. ${ }^{10}$ Finally, high incidence of spontaneous tumors in mice with monoallelic disruption of Beclin 1 has provided strong genetic evidence for autophagy-mediated suppression of tumorigenesis. ${ }^{18,19}$
In this report, we identify two opposing roles for Beclin 1 in the control of tumor cell growth, that is, sensitization to autophagy and requirement for cell proliferation. Restoration of normal Beclin 1 levels in MCF-7 breast cancer cells that have monoallelic deletion of beclin 1 gene greatly sensitized them to autophagy. Whereas the antiproliferative effect of Beclin 1 in starved MCF-7 cells is due to autophagy-mediated inhibition of cell proliferation, ${ }^{40}$ our data show that Beclin 1 expression dramatically increased EB1089-induced autophagy-dependent cell death. Both the kinetics and the extent of EB1089-induced death were greatly accelerated in cells expressing ectopic Beclin 1. The downregulation of autophagic activity in malignant cells may thus promote tumor growth both by increasing the growth rate and by allowing the tumor cells to escape autophagic cell death. If autophagy was a purely antitumorigenic mechanism, its inhibition should enhance tumor cell proliferation and survival. However, the knock down of the remaining Beclin 1 expression in MCF-7 cells almost completely inhibited cell proliferation in normal culture conditions. Similar growth inhibition was observed in HeLa cervix carcinoma cells suggesting that some Beclin 1 is necessary for tumor cell growth. This hypothesis is supported 
by earlier data showing that contrary to most known tumor suppressor genes that commonly show loss of heterogeneity, the wild-type beclin 1 allele has never been found mutated nor silenced in tumors occurring in beclin 1 heterozygous mice or human breast carcinoma cell lines. ${ }^{18,19,41}$ It remains to be studied whether the requirement for Beclin 1 in cell proliferation is specific for cancer cells. Beclin 1 is, however, not required for the proliferation of embryonic stem cells under standard culture condition or for the early growth of embryonic tissues. ${ }^{19}$ Beclin 1-deficient embryos are, however, smaller than wild-type embryos and they die around embryonic day 8 , because of their inability to undergo remodeling and proper differentiation of ventral endoderm. ${ }^{19}$ It should also be noted that it is as yet unclear whether the dependence of tumor cells on Beclin 1 is due to its essential role in autophagy or whether it mediates an autophagy-independent survival or growth function in tumor cells. The former is supported by data showing that autophagy can suppress latent and stressinduced apoptotic programs. ${ }^{11,16,25,26}$ The autophagymediated cytoprotective effect could be brought about by recycling of nutrients and/or removal of damaged organelles including mitochondria that would otherwise release cytochrome $c$ or oxidative radicals and initiate caspase activation or oxidative stress response, respectively.

Contrary to earlier reports suggesting that TNF induces autophagy, ${ }^{11,17}$ TNF-induced increase in VAC and MDC staining in MCF-7 cells reflected increased lysosomal volume rather than autophagy. TNF failed to trigger autophagosome formation as analyzed by the translocation of DsRed1-LC3- $\beta$ into the vacuolar structures and by EM. Furthermore, the regulation of autophagic activity by $3-\mathrm{MA}$ and Beclin 1 expression failed to affect the survival of TNF-treated cells. Similarly, TG-induced cell death was unaffected by altering autophagic activity. Instead, TG induced a massive lysosomal membrane permeabilization that was reflected by almost complete disappearance of all acidic vacuoles and a release of all lysosomal cathepsins into the cytosol. It has been suggested that a partial lysosomal leakage would result in apoptosis-like PCD, whereas the massive leakage would lead to the disruption of the plasma membrane and necrotic death. ${ }^{42}$ TG-treated cells showed, however, mainly apoptosis-like changes like nuclear and chromatin condensation as well as DNA fragmentation rather than necrosis-associated mitochondrial swelling or massive plasma membrane lysis.

MDC has been reported to specifically label autophagic vesicles, ${ }^{33}$ and it has been widely used as a marker for autophagy. Our data severely question the specificity of this probe. The intensity of the MDC staining was increased and it colocalized with lysotracker-red even in TNF-treated MCF-7 cells where no autophagy could be detected by DsRed1-LC3$\beta$ staining or by EM. Furthermore, MDC failed to stain a large proportion of DsRed1-LC3- $\beta$-positive vacuoles in EB1089and tamoxifen-treated autophagic cells. Thus, MDC appears to stain the acidic vacuoles (lysosomes and autolysosomes) of the cells rather than autophagosomes, and previous data reporting autophagy based on MDC uptake should be carefully re-evaluated. In addition to demonstration of autophagic vesicles by EM, changes in the intracellular localization of LC3- $\beta$ appear as a reliable method to detect autophagy. The characterization of the molecular basis of autophagy will hopefully provide even more reliable biochemical methods in the near future.

Contrary to most reported autophagy models, where autophagy-mediated antiproliferative effects are mainly due to the cell cycle arrest, ${ }^{16,26,40}$ EB1089-induced autophagy was associated with apoptosis-like cell death characterized by chromatin condensation and DNA fragmentation. Nuclear apoptosis did not only occur in the same cells that showed autophagic morphology but in fact depended on autophagic activity since 3-MA effectively inhibited and overexpression of Beclin 1 enhanced both DNA fragmentation and chromatin condensation. Thus, instead of serving as an adaptive response to maintain continual cell survival under stress conditions, EB1089-induced autophagy appears causal to the cell death. Whether this difference in outcome of autophagy induction is due to different signaling pathways involved or the severity of the response is still unknown.

The discovery of an EB1089-induced autophagic cell death pathway suggests that this compound could be useful in the treatment of cancers mutated in the signaling pathways leading to apoptosis. Moreover, a combination therapy using drugs inducing PCD through different signaling pathways would make it harder for cancer cells to escape death and develop drug resistance. Accordingly, combinations of the active form of vitamin $\mathrm{D}$ or its analogues with other cytotoxic agents such as TNF, Taxol, doxorubicin and radiation show synergistic effects. ${ }^{30,43,44}$ Finding of the optimal therapy combinations will, however, require a more detailed understanding of the EB1089-induced signaling pathways leading to autophagy and PCD. Furthermore, our surprising data showing that tumor cell growth depends on Beclin 1 opens the possibility that inhibitors of autophagy or specific inhibitors of Beclin 1 may prove effective in the treatment of tumors that have lost one allele of Beclin 1 and/or have defects in other autophagy stimulating tumor suppressor genes. In addition to inhibiting tumor cell growth, such treatments may sensitize cells to classic apoptosis pathway.

\section{Materials and Methods}

\section{Cell culture and treatments}

The MCF-7S1 cell line is a subclone of the human ductal breast carcinoma cell line MCF-7 selected for high TNF sensitivity, ${ }^{45}$ and HeLa cell line originates from a human cervix carcinoma (kindly provided by Jiri Bartek, Danish Cancer Society, Copenhagen, Denmark). The cells were cultured in RPMI 1640 with Glutamax (Life Technologies, Lts., Paisley, UK) supplemented with $6 \%$ heat-inactivated fetal calf serum (FCS; Biological Industries, Kib. Beit Haemek, Israel), $100 \mathrm{U} / \mathrm{ml}$ penicillin and $100 \mu \mathrm{g} / \mathrm{ml}$ streptomycin. The medium of the stably transfected cells contained also $400 \mu \mathrm{g} / \mathrm{ml}$ Geneticin sulfate (G-418; Invitrogen, Carlsbad, CA, USA). The cells were maintained in a humidified atmosphere at $37^{\circ} \mathrm{C}, 5 \% \mathrm{CO}_{2}, 21 \%$ $\mathrm{O}_{2}, 74 \% \mathrm{~N}_{2}$, and regularly tested and found negative for mycoplasma infection.

EB1089 and 1,25-dihydroxyvitamin $D_{3}$ were kindly provided by Christina Mørk Hansen and Lise Binderup (LEO Pharmaceutical Products, Ballerup, Denmark) and human TNF by Anthony Cerami (Kenneth Warren Laboratories, Tarrytown, NY, USA). TG, rapamycin, tamoxifen and 3-MA were purchased from Sigma-Aldrich (St. Louis, MO, USA). For 2-, 3- and 5-day experiments, cells were seeded at densities 16-30000, 8-15000 
and 3-6000 cells $/ \mathrm{cm}^{2}$, respectively, $20 \mathrm{~h}$ before the indicated treatments. Tamoxifen-treated cells and the corresponding vehicle-treated cells were cultured in a phenol red-free DMEM/F12 medium (Life Technologies) containing $18 \%$ active coal-stripped FCS (kindly provided by Jan Stenvang Jepsen, Danish Cancer Society).

\section{Cloning and transfections}

Cells were transfected by electroporation $(960 \mu \mathrm{F}, 330 \mathrm{~V})$ essentially as described previously, ${ }^{45}$ and when indicated single cell clones were obtained by limited dilution. The CDNA encoding for human LC3- $\beta$ protein was PCR amplified from MCF10A cDNA library (kindly provided by Mads Daugaard Jensen, Danish Cancer Society) by a standard procedure employing Pfu Turbo Polymerase (Stratagene, La Jolla, CA, USA), $5^{\prime}$-end primer containing an Xhol restriction enzyme cleavage site and bases 80-99 (5'CTCGAGGCACCATGCCGTCGGAGAAG3') of the LC3- $\beta$ sequence (NM_022818) and $3^{\prime}$-end primer ( $5^{\prime}$ GATCTCAGTTGGTAACACC $\mathrm{C}^{\prime}$ ) complementary to bases $521-540$ of LC3- $\beta$. In order to create the pDsRed-LC3- $\beta$ plasmid, the obtained PCR product was cloned into pCR2.1-TOPO (Invitrogen, Paisley, UK), cleaved with Xhol and EcoRI and subcloned in frame downstream of the DsRed1 sequence in pDsRed1-C1 (kindly provided by Juliane Jürgensmeier, University of Cologne, Germany). The appropriate sequence was confirmed by sequencing (Microsynth $\mathrm{GmbH}$, Lindau, Switzerland). The pCR3.1-FLAG-Beclin ${ }^{40}$ was kindly provided by Beth Levine (Columbia University, New York, NY, USA) and $\mathrm{pH} 2 \mathrm{~B}$-eGFP-N1 encoding for a fusion protein consisting of histone $2 \mathrm{~B}$ and eGFP was a gift from Christian Holmberg (University of Copenhagen, Denmark).

Two nonoverlapping siRNAs corresponding to the human CDNA sequence for beclin-1 (5'CAGTTTGGCACAATCAATA3' and 5'CAGGAA CTCACAGCTCCAT3') and a control siRNA (5'CGACCGAGACAAGCG CAAG3') where purchased from Dharmacon Research (USA). MCF-7 and HeLa cells were transfected with 50 and $25 \mathrm{nM}$ siRNA, respectively, applying oligofectamin (Invitrogen) as a transfection agent.

\section{Measurement of cell viability and death}

The viability of cells was analyzed by the MTT reduction assay as described previously. ${ }^{29}$ The DNA fragmentation (cytosolic histone-bound DNA) was determined using the Cell Death Detection ELISA ${ }^{\text {plus }}$ kit (Roche, Mannheim, Germany) and a microtiter plate reader (VERSA max $_{\text {, }}$ Molecular Devices LTd, Crawley, UK) according to the manufacture's instructions. The results were normalized to the cell number in cultures treated in parallel, and displayed as arbitrary units. Phase contrast pictures were taken with an inverted Olympus IX-70 microscope connected to an Olympus C-5050 digital camera using $\times 20$ objective with numerical aperture 1.1. \pm 0.5 . Image processing was performed with Adobe Photoshop 7.0. Membrane integrity was analyzed by staining cells with 1-2 $\mu$ M SYTOX Green (S-7020, Molecular Probes) for $10 \mathrm{~min}$, washed in PBS supplemented with $5 \%$ FCS and analysed by the FL1-H channel of flow cytometry (Becton Dickinson, San Jose, CA, USA).

\section{Visualization and analyses of intracellular vacuoles}

The acidic compartment of cells was analyzed by labeling the cells with $50 \mathrm{nM}$ lysotracker-red (Molecular Probes, Eugene, OR, USA) for 10$15 \mathrm{~min}$ and applying Zeiss Axiovert $100 \mathrm{M}$ Confocal Laser Scanning Microscope equipped with LSM510 system using $\times 40$ Plan-neofluar objective with numerical aperture 1.3.
MDC (Sigma-Aldrich) was applied to the cells at $50 \mu \mathrm{M}$ for $30-45 \mathrm{~min}$ followed by $10 \mathrm{~min}$ incubation with $40 \mathrm{mM} \mathrm{NH}_{4} \mathrm{Cl}$ in order to reduce the lysosomal staining and one wash with phosphate-buffered saline (PBS) plus $10 \% \mathrm{FCS}$. $\mathrm{NH}_{4} \mathrm{Cl}$ treatment was omitted when costaining with lysotracker-red. Pictures were taken on an inverted fluorescence microscope (Olympus IX-70) with Olympus C-5050 digital camera. The intracellular MDC-fluorescence (excitation $355 \mathrm{~nm}$, emission 460, cutoff 550 , well-scan) was quantified by a Spectramax Gemini fluorometer (Molecular Devices, Sunnyvale, CA, USA). The MDC fluorescence intensity was correlated to cell density as measured by MTT reduction assay performed in parallel treated samples. The results are expressed as fluorescence/cell relative to untreated control cells.

\section{DsRed1-LC3- $\beta$ translocation}

Exponentially growing cells were transfected with pDsRed1-LC3- $\beta$ together with pH2B-eGFP-N1 $(4: 1)$ by electroporation and seeded 1 day after the transfection on glass chamber slides (\#155379, Nalge Nunc International, Roskilde, Denmark). After indicated treatments, the percentage of green cells (a minimum of 100 cells/sample) with red vacuoles (DsRed1-LC3- $\beta$ translocated from cytosol to autophagic vacuoles) was counted applying Zeiss Axiovert $100 \mathrm{M}$ Confocal Laser Scanning Microscope.

\section{Measurement of protein degradation}

Cells were labeled for $24 \mathrm{~h}$ with $0.2 \mu \mathrm{Ci} / \mathrm{ml}{ }^{14} \mathrm{C}$-Valine (Amersham Biosciences) in culture medium, washed three times with PBS and incubated for $1 \mathrm{~h}$ in culture medium before adding the indicated stimuli in fresh medium. The media and stimuli were replaced every $24 \mathrm{~h}$. At the time of harvesting, the culture medium was collected and the cells were trypsinized. Cellular proteins were precipitated with $10 \%$ trichloroacetic acid at $4^{\circ} \mathrm{C}$ for $10 \mathrm{~min}$ and centrifuged at $1000 \mathrm{~g}$ for $20 \mathrm{~min}$. The radioactivity in the culture media and the acid-insoluble pellet were determined in a scintillation counter (Wallac, Turku, Finland). The rate of protein degradation was calculated as the level of radioactivity in the culture medium divided by the total radioactivity and is expressed as percent increase upon indicated treatments.

\section{Cysteine Cathepsin activity measurements}

After removing the medium, $200 \mu$ lextraction buffer ( $250 \mathrm{mM}$ sucrose, $20 \mathrm{mM}$ HEPES, $10 \mathrm{mM} \mathrm{KCl}, 1.5 \mathrm{mM} \mathrm{MgCl} 21 \mathrm{mM}$ EDTA, $1 \mathrm{mM}$ EGTA, $1 \mathrm{mM}$ pefabloc SC, pH 7.5) containing $20 \mu \mathrm{g} / \mathrm{ml}$ (cytoplasmic fraction) or $200 \mu \mathrm{g} / \mathrm{m}$ (total cellular fraction) digitonin was added and plates were kept on ice with a gentle shaking for $12 \mathrm{~min}$. The enzyme activity of the samples was determined as described previously employing z-FR-amino-trifluoromethylcoumarin (Enzyme System Products) as substrate for cysteine cathepsins and Spectramax Gemini fluorometer (Molecular Devices, Sunnyvale, CA, USA) for the measurement of Vmax of the liberation of the fluorochrome. ${ }^{6}$ All protease activities were normalized to the lactate dehydrogenase activity analyzed by cytotoxicity detection kit (Roche) of the same sample.

\section{Immunoblot analysis}

Immunodetection was performed using mouse monoclonal antibodies against Beclin 1 (clone 20; BD Transduction Laboratories; at 1:200), FLAG (clone M2; Sigma-Aldrich; at 1:100), heat-shock cognate 70 protein (Hsc70; clone N69 kindly provided by Boris Margulis, Russian 
Academy of Sciences, St. Petersburg, Russia; at 1:4000) and GAPDH (Biogenesis, Poole, UK; at 1:5000) as primary antibodies, appropriate peroxidase-conjugated secondary antibodies from DAKO A/S and ECL Western blotting reagents from Amersham Pharmacia. The IMAGEJ densitometry software was used to quantify the protein levels.

\section{Transmission and cryo immuno EM}

Subconfluent cells fixed in situ for $10 \mathrm{~min}$ in $50 \%$ Karnovsky fixative were collected by scraping with a rubber policeman, transferred to a centrifugation tube and centrifuged at $1500 \mathrm{~g}$ for $5 \mathrm{~min}$. The pellet was washed and stored in $70 \%$ Karnovsky fixative at $4{ }^{\circ} \mathrm{C}$ until embedding. After washing in $0.1 \mathrm{M}$ cacodylate buffer, the pellet was embedded in $2 \%$ agar, cut into smaller cubes, postfixed in osmium, dehydrated and embedded in Epon according to standard procedures. Ultrathin sections cut on an RMC, MT-7 ultramicrotome were collected on copper grids and stained with $4 \%$ uranyl-acetate and Reynolds lead-citrate for ultrastructural examination in a JEOL 1210 electron microscope.

For cryo immuno-EM cells were fixed for $30 \mathrm{~min}$ in $4 \%$ paraformaldehyde in $0.1 \mathrm{M}$ phosphate buffer (PB) and washed in $0.1 \mathrm{M} \mathrm{PB}$. The pellet was embedded in $15 \%$ gelatine (Merck art 4078) in $0.1 \mathrm{M} \mathrm{PB}$ for $20 \mathrm{~min}$ at $37^{\circ} \mathrm{C}$, centrifuged at 6000 r.p.m. for $5 \mathrm{~min}$ (Sigma $202 \mathrm{MC}$ centrifuge), hardened for $20 \mathrm{~min}$ at $4^{\circ} \mathrm{C}$, cut into $1 \mathrm{~mm}^{3}$ cubes that were cryo-protected by soaking in 2.3 M PB-buffered sucrose containing $1 \%$ paraformaldehyde at $4{ }^{\circ} \mathrm{C}$ for $18 \mathrm{~h}$ and frozen on silver stubs in liquid nitrogen. Ultrathin cryosections were cut on a Leica Ultracut UCT/EM FCS cryo ultramicrotome and collected on 200 mesh Formvar-coated nickel grids. A two- or three-layer indirect immunostaining was used as previously described. ${ }^{46}$ The primary antibodies used included monoclonal mouse antibodies against cathepsin D (M 7243, Dako A/S, Glostrup, Denmark; at $1.76 \mathrm{mg} / \mathrm{l})$, serca-2 ATPase (\#564702, Calbiochem, La Jolla, CA, USA; at $1: 300)$, cytochrome $c(\# 556432$, BD PharMingen, San Diego, CA USA; at $2.5 \mathrm{mg} / \mathrm{l}), \mathrm{Hsp} 60$ (SPA-806, StressGen, Victoria, B.C., Canada; at $5.0 \mathrm{mg} / \mathrm{l})$ and polyclonal rabbit antiserum against cathepsin D (A 0561, Dako A/S; at $1: 300)$. The secondary antibodies in two- and three-layer indirect immunostainings were $F(a b)_{2}$ goat anti-rabbit IgG Ultra-Small (100166, AURION, Wageningen, The Netherlands) and biotinylated rabbit antimouse $F(a b)_{2} \lg G(E 0413$, Dako A/S; at 1:400), respectively, and the tertiary antibody was goat anti-biotin Ultra-Small (100088, AURION). Mouse IgG1 (X 0931, Dako A/S; 2.5- or $5 \mathrm{mg} / \mathrm{ml}$ ) served as a control.

The sections were silver enhanced using AURION R-GENT silver enhancer (500033, AURION). For contrast and protection against airdrying artefacts, sections were incubated in $2 \%$ methyl cellulose containing $0.4 \%$ uranyl acetate before viewing in a JEOL 1210 electron microscope.

\section{Measurement of DNA synthesis}

Cell proliferation was measured by labeling with 5-bromo-2'-deoxy-Uridine (BrdU) incorporation. Cells growing on coverslips were pulsed with $100 \mu \mathrm{M}$ BrdU (Sigma-Aldrich) for 20-25 min, followed by three washes in cold PBS, fixation in $3.7 \%$ formaldehyde (Sigma-Aldrich) for $20 \mathrm{~min}$ and permeabilization in $0.2 \%$ Triton-X-100 for 4 min. After six washes in PBS, the slides were treated with $10 \mathrm{U} / \mathrm{ml}$ DNasel (Boehringer Mannheim, Mannheim, Germany) for $30 \mathrm{~min}$, washed, incubated for $1 \mathrm{~h}$ with $1: 300$ anti-BrdU antibody (\#RPN202, Amersham, Little Chalfont, UK) in PBS containing 10\% FCS, washed and incubated with Alexa ${ }^{\mathrm{TM}} 488$ goat-antimouse IgG (Molecular Probes) diluted 1:500 in PBS containing 10\% FCS for $1 \mathrm{~h}$. After six washes, the cells were mounted on glass slides and the percentage of BrdU-positive cells was counted applying Zeiss Axiovert $100 \mathrm{M}$ Confocal Laser Scanning Microscope.

\section{Statistical analysis}

Independent experiments were pooled when the coefficient of variance could be assumed identical. Statistical significance was evaluated using one or two sample $t$-tests ( $n=$ number of independent experiments).

\section{Acknowledgements}

We thank Mikkel Rohde, Thomas Farkas, Birgit Poulsen, Karina Grøn Henriksen, Anja Groth and Donna Czerny for excellent technical assistance and Lise Binderup, Jiri Bartek, Anthony Cerami, Christina Mørk Hansen, Christian Holmberg, Mads Daugaard Jensen, Jan Stenvang Jepsen, Juliane Jürgenmeier, Beth Levine and Boris Margulis for invaluable research tools. This work was supported by grants from the Danish Cancer Society (MHH and MJ), the Danish Medical Research Council (MJ), the Association for International Cancer Research (MJ) and the John and Birthe Meyer Foundation (MJ).

\section{References}

1. Leist $M$ and Jäättelä $M$ (2001) Four deaths and a funeral: from caspases to alternative mechanisms. Nat. Rev. Mol. Cell Biol. 2: 589-598

2. Jäättelä $M$ (2004) Multiple cell death pathways as regulators of tumour initiation and progression. Oncogene 23: 2746-2756

3. Guicciardi ME, Leist M and Gores GJ (2004) Lysosomes in cell death. Oncogene 23: 2881-2890

4. Roberg K, Kagedal K and Ollinger K (2002) Microinjection of cathepsin d induces caspase-dependent apoptosis in fibroblasts. Am. J. Pathol. 161: 89-96

5. Boya P, Andreau K, Poncet D, Zamzami N, Perfettini JL, Metivier D, Ojcius DM, Jäättelä $M$ and Kroemer $G$ (2003) Lysosomal membrane permeabilization induces cell death in a mitochondrion-dependent fashion. J. Exp. Med. 197: 1323-1334

6. Foghsgaard L, Wissing D, Mauch D, Lademann U, Bastholm L, Boes M, Elling $F$, Leist $M$ and Jäättelä $M(2001)$ Cathepsin $B$ acts as a dominant execution protease in tumor cell apoptosis induced by tumor necrosis factor. J. Cell Biol. 153: 999-1009

7. Nylandsted J, Gyrd-Hansen M, Danielewich A, Fehrenbacher N, Lademann U, Høyer-Hansen M, Multhoff G, Rohde M and Jäättelä M (2004) Hsp70 promotes cell survival by inhibiting lysosomal membrane permeabilization. J. Exp. Med. 200: 425-435

8. Fehrenbacher N, Gyrd-Hansen M, Poulsen B, Felbor U, Kallunki T, Boes M, Weber E, Leist M and Jäättelä M (2004) Sensitization to the lysosomal death pathway upon immortalization and transformation. Cancer Res. 64: 5301-5310

9. Gozuacik D and Kimchi A (2004) Autophagy as a cell death and tumor suppressor mechanism. Oncogene 23: 2891-2906

10. Chi S, Kitanaka C, Noguchi K, Mochizuki T, Nagashima Y, Shirouzu M, Fujita H, Yoshida M, Chen W, Asai A, Himeno M, Yokoyama S and Kuchino Y (1999) Oncogenic Ras triggers cell suicide through the activation of a caspaseindependent cell death program in human cancer cells. Oncogene 18: 2281-2290

11. Inbal B, Bialik S, Sabanay I, Shani G and Kimchi A (2002) DAP kinase and DRP-1 mediate membrane blebbing and the formation of autophagic vesicles during programmed cell death. J. Cell Biol. 157: 455-468

12. Chau YP, Lin SY, Chen JH and Tai MH (2003) Endostatin induces autophagic cell death in EAhy926 human endothelial cells. Histol. Histopathol. 18: 715-726

13. Paglin S, Hollister T, Delohery T, Hackett N, McMahill M, Sphicas E, Domingo D and Yahalom J (2001) A novel response of cancer cells to radiation involves autophagy and formation of acidic vesicles. Cancer Res. 61: 439-444

14. Bursch W, Ellinger A, Kienzl H, Torok L, Pandey S, Sikorska M, Walker R and Hermann RS (1996) Active cell death induced by the anti-estrogens tamoxifen 
and ICl 164384 in human mammary carcinoma cells (MCF-7) in culture: the role of autophagy. Carcinogenesis 17: 1595-1607

15. Opipari Jr AW, Tan L, Boitano AE, Sorenson DR, Aurora A and Liu JR (2004) Resveratrol-induced autophagocytosis in ovarian cancer cells. Cancer Res. 64 $696-703$

16. Kanzawa T, Germano IM, Komata T, Ito H, Kondo Y and Kondo S (2004) Role of autophagy in temozolomide-induced cytotoxicity for malignant glioma cells. Cell Death Differ. 11: 448-457

17. Jia L, Dourmashkin RR, Allen PD, Gray AB, Newland AC and Kelsey SM (1997) Inhibition of autophagy abrogates tumour necrosis factor alpha induced apoptosis in human T-lymphoblastic leukaemic cells. Br. J. Haematol. 98: 673-685

18. Qu X, Yu J, Bhagat G, Furuya N, Hibshoosh H, Troxel A, Rosen J, Eskelinen EL, Mizushima N, Ohsumi Y, Cattoretti G and Levine B (2003) Promotion of tumorigenesis by heterozygous disruption of the beclin 1 autophagy gene. J. Clin. Invest. 112: 1809-1820

19. Yue Z, Jin S, Yang C, Levine AJ and Heintz N (2003) Beclin 1, an autophagy gene essential for early embryonic development, is a haploinsufficient tumor suppressor. Proc. Natl. Acad. Sci. USA 100: 15077-15082

20. Clarke PG (1990) Developmental cell death: morphological diversity and multiple mechanisms. Anat. Embryol. (Berl) 181: 195-213

21. Xue L, Fletcher GC and Tolkovsky AM (1999) Autophagy is activated by apoptotic signalling in sympathetic neurons: an alternative mechanism of death execution. Mol. Cell. Neurosci. 14: 180-198

22. Yu L, Alva A, Su H, Dutt P, Freundt E, Welsh S, Baehrecke EH and Lenardo MJ (2004) Regulation of an ATG7-beclin 1 program of autophagic cell death by caspase-8. Science 304: 1500-1502

23. Saeki K, Yuo A, Okuma E, Yazaki Y, Susin SA, Kroemer G and Takaku F (2000) Bcl-2 down-regulation causes autophagy in a caspase-independent manner in human leukemic HL60 cells. Cell Death Differ. 7: 1263-1269

24. Caro LH, Plomp PJ, Wolvetang EJ, Kerkhof C and Meijer AJ (1988) 3Methyladenine, an inhibitor of autophagy, has multiple effects on metabolism. Eur. J. Biochem. 175: 325-329

25. Bauvy C, Gane P, Arico S, Codogno P and Ogier-Denis E (2001) Autophagy delays sulindac sulfide-induced apoptosis in the human intestinal colon cancer cell line HT-29. Exp. Cell Res. 268: 139-149

26. Komata T, Kanzawa T, Nashimoto T, Aoki H, Endo S, Nameta M, Takahashi H, Yamamoto T, Kondo S and Tanaka R (2004) Mild heat shock induces autophagic growth arrest, but not apoptosis in U251-MG and U87-MG human malignant glioma cells. J. Neurooncol. 68: 101-111

27. Scott RC, Schuldiner $O$ and Neufeld TP (2004) Role and regulation of starvation-induced autophagy in the Drosophila fat body. Dev. Cell 7: 167-178

28. Hansen CM, Binderup L, Hamberg KJ and Carlberg C (2001) Vitamin D and cancer: effects of $1,25(\mathrm{OH}) 2 \mathrm{D} 3$ and its analogs on growth control and tumorigenesis. Front Biosci. 6: D820-D848

29. Mathiasen IS, Lademann U and Jäättelä M (1999) Apoptosis induced by vitamin $\mathrm{D}$ compounds in breast cancer cells is inhibited by Bcl-2 but does not involve known caspases or p53. Cancer Res. 59: 4848-4856

30. Mathiasen IS, Hansen CM, Foghsgaard L and Jäättelä M (2001) Sensitization to TNF-induced apoptosis by 1,25-dihydroxy vitamin $D(3)$ involves upregulation of the TNF receptor 1 and cathepsin B. Int. J. Cancer 93: 224-231
31. Mathiasen IS, Sergeev IN, Bastholm L, Elling $F$, Norman AW and Jäättelä $M$ (2002) Calcium and calpain as key mediators of apoptosis-like death induced by vitamin D compounds in breast cancer cells. J. Biol. Chem. 277: 30738-30745

32. Jackisch C, Hahm HA, Tombal B, McCloskey D, Butash K, Davidson NE and Denmeade SR (2000) Delayed micromolar elevation in intracellular calcium precedes induction of apoptosis in thapsigargin-treated breast cancer cells. Clin. Cancer Res. 6: 2844-2850

33. Biederbick A, Kern HF and Elsasser HP (1995) Monodansylcadaverine (MDC) is a specific in vivo marker for autophagic vacuoles. Eur. J. Cell Biol. 66: 3-14

34. Seglen PO and Gordon PB (1982) 3-Methyladenine: specific inhibitor of autophagic/lysosomal protein degradation in isolated rat hepatocytes. Proc. Natl. Acad. Sci. USA 79: 1889-1892

35. Noda T and Ohsumi Y (1998) Tor, a phosphatidylinositol kinase homologue, controls autophagy in yeast. J. Biol. Chem. 273: 3963-3966

36. He H, Dang Y, Dai F, Guo Z, Wu J, She X, Pei Y, Chen Y, Ling W, Wu C, Zhao S, Liu JO and Yu L (2003) Post-translational modifications of three members of the human MAP1LC3 family and detection of a novel type of modification for MAP1LC3B. J. Biol. Chem. 278: 29278-29287

37. Kabeya Y, Mizushima N, Ueno T, Yamamoto A, Kirisako T, Noda T, Kominami E, Ohsumi Y and Yoshimori T (2000) LC3, a mammalian homologue of yeast Apg8p, is localized in autophagosome membranes after processing. EMBO J. 19: $5720-5728$

38. Price BD, Mannheim-Rodman LA and Calderwood SK (1992) Brefeldin A, thapsigargin, and AIF4- stimulate the accumulation of GRP78 mRNA in a cycloheximide dependent manner, whilst induction by hypoxia is independent of protein synthesis. J. Cell Physiol. 152: 545-552

39. Dunn Jr WA (1990) Studies on the mechanisms of autophagy: maturation of the autophagic vacuole. J. Cell Biol. 110: 1935-1945

40. Liang XH, Jackson S, Seaman M, Brown K, Kempkes B, Hibshoosh $\mathrm{H}$ and Levine B (1999) Induction of autophagy and inhibition of tumorigenesis by beclin 1. Nature 402: $672-676$

41. Aita VM, Liang XH, Murty VV, Pincus DL, Yu W, Cayanis E, Kalachikov S, Gilliam TC and Levine B (1999) Cloning and genomic organization of beclin 1, a candidate tumor suppressor gene on chromosome 17q21. Genomics 59: 59-65

42. Kågedal K, Zhao M, Svensson I and Brunk UT (2001) Sphingosine-induced apoptosis is dependent on lysosomal proteases. Biochem. J. 359: 335-343

43. Wang Q, Yang W, Uytingco MS, Christakos S and Wieder R (2000) 1,25Dihydroxyvitamin D3 and all-trans-retinoic acid sensitize breast cancer cells to chemotherapy-induced cell death. Cancer Res. 60: 2040-2048

44. Sundaram S, Sea A, Feldman S, Strawbridge R, Hoopes PJ, Demidenko E, Binderup L and Gewirtz DA (2003) The combination of a potent vitamin D3 analog, EB 1089, with ionizing radiation reduces tumor growth and induces apoptosis of MCF-7 breast tumor xenografts in nude mice. Clin. Cancer Res. 9: 2350-2356

45. Jäättelä M, Benedict M, Tewari M, Shayman JA and Dixit VM (1995) Bcl-x and Bcl-2 inhibit TNF and Fas-induced apoptosis and activation of phospholipase $\mathrm{A}_{2}$ in breast carcinoma cells. Oncogene 10: 2297-2305

46. Bastholm L, Elling F, Brünner N and Nielsen M (1994) Immunoelectron microscopy of the receptor for urokinase plasminogen activator and Cathepsin $D$ in the human breast cancer cell line MDA-MB-231. APMIS 102: 279-286 